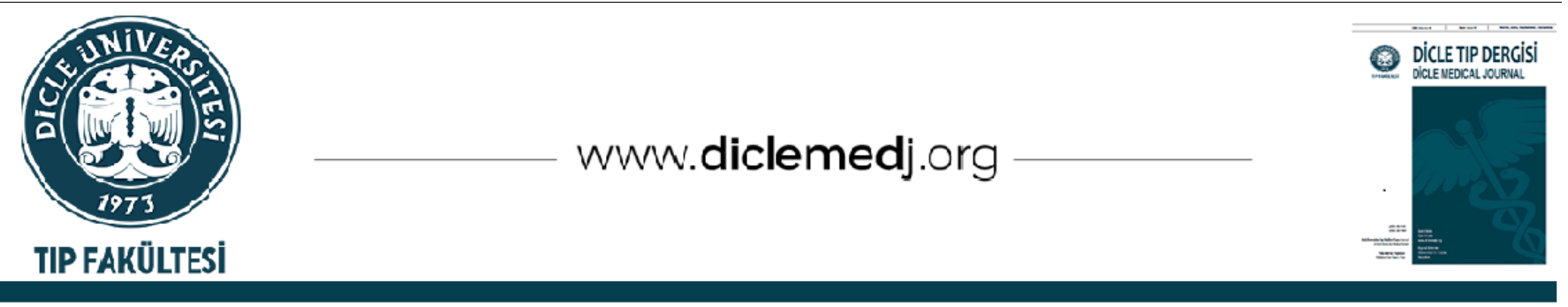

Derleme / Review

\title{
Çocuklarda CovíD-19 ve Yoğun Bakım Yönetimi
}

\author{
Velat Şen ${ }^{1}$, Hasan Zan ${ }_{2}$ \\ 1 Dicle Üniversitesi Tıp Fakültesi Çocuk Göğüs Hastalıkları AD, Diyarbakır, Türkiye \\ 2 Dicle Üniversitesi Tıp Fakültesi Çocuk Sağlığı ve Hastalıkları AD, Diyarbakır, Türkiye \\ Geliş: 28.09.2021; Kabul Tarihi: 29.09.2021
}

Öz

Aralık 2019'da Çin'in Wuhan eyaletinde yeni bir tip koronavirüs enfeksiyonu ortaya çıtı ve hızla yayılmaya başladı. Hastalığa neden olan virüs şiddetli akut solunum yolu sendromu coronavirüs-2 (SARS-CoV-2) olarak bildirilmiştir. 0 zamandan beri virüs dünya çapında 200'den fazla ülkeyi etkiledi ve küresel bir salgına neden oldu. Günümüzde, COVID19 pandemisi tüm dünyayı etkisi altına almaya devam ediyor.

COVID-19 hastalığı çocuklarda yetişkinlere göre daha hafif veya asemptomatik seyretmekle beraber zaman ilerledikçe, COVID-19' a bağlı kritik hasta çocuk sayısında artış görülmeye başlanmıştır. Biz bu derlemede kritik COVID-19 çocuk hastalarının takip ve tedavisini güncel kılavuzlar ışığında sunmayı planladık.

Anahtar kelimeler: Çocuk - COVID-19 - Yoğun Bakım

\section{COVID-19 In Children: Intensive Care Management}

\begin{abstract}
In December 2019, a novel type of coronavirus infection emerged in the Wuhan province of China and began to spread rapidly. The disease is caused by severe acute respiratory syndrome coronavirus-2 (SARS-CoV-2). Since then, the virus has affected more than 200 countries worldwide and caused a global pandemic. COVID-19 pandemic continues to have a growing impact on the whole world.

Although COVID-19 disease have milder or asymptomatic course in children compared to adults, as time progresses, the number of critically ill children due to COVID-19 has begun to increase. In this review, we planned to present the followup and treatment of critical COVID-19 pediatric patients in the light of current guidelines.
\end{abstract}

Keywords: Child - COVID-19 - Intensive Care.

\section{DOI: 10.5798/dicletip.1005373}

Yazışma Adresi / Correspondence: Velat Şen, Dicle Üniversitesi Tıp Fakültesi Çocuk Sağlığı ve Hastalıkları AD, Diyarbakır, Türkiye e-mail: drvelatsen@hotmail.com 


\section{GíRiş}

Koronovirüsler memelilerde, kuşlarda ve insanlarda hastalık yapabilen tek zincirli, pozitif polariteli, zarflı RNA virüslerinden oluşan büyük bir zoonotik virüs ailesidir. Yüzeylerinde çubuksu glikoprotein uzantıları vardır. $\mathrm{Bu}$ uzantılar, Latince'de "corona" kelimesi "taç " anlamına geldiği için bu virüslere Coronavirus (taçlı virüs) ismi verilmiştir ${ }^{1}$.

SARS-CoV-2 virüsünün kökeni ile ilgili çok spekülatif değerlendirmeler olmakla birlikte Çin'in Hubei eyaletinde bir şehir olan Wuhan'da hayvanlar aracılığıyla insanlara bulaştığı bildirilmiştir ${ }^{2}$. Ağır solunum sıkıntısı sendromuna yol açan virüse (SARS-CoV) benzerliği nedeni ile SARS-CoV-2 ismi verilmiștir. Daha sonrasında bu virüsün neden olduğu hastalık COVID-19 olarak isimlendirilmiştir ${ }^{3}$.

COVID-19 ilk olarak Aralık 2019'da Wuhan kentinden başlayıp dünya çapında yaklaşık 6 ay içerisinde bir milyondan fazla insanının ölümü ile ilişkilendirilen bir pandemiye neden olmuştur. Günümüze kadar bu hastalık ile ilişkili ölüm sayısı 4.5 milyonu aşmış bulunmaktadır.

Enfeksiyonun bulaşması, enfekte damlacıkların solunması veya doğrudan temas yoluyla gerçekleşiri ${ }^{3}$. Virüsün yüzeylerde tam canlılık süresi birkaç saat ile birkaç gün arasında değişmekle birlikte daha yüksek sıcaklık ve düşük nem koşullarında önemli ölçüde düşmektedir ${ }^{4}$.

Çin'de Ocak 2020'de doğrulanmış ilk pediatrik SARS-CoV-2 vakası bildirilmiştir ${ }^{5}$.

COVID-19'lu çocuklar genellikle hafif bir klinik prezentasyona sahiptir. Çocuk hastalarda belirti ve bulgular; öksürük, ateş, boğaz ağrısı, burun akıntısı, baş ağrısı, kas ağrısı, nefes darlığı, ishal, kusma, takipne ve taşikardi olarak görülebilmektedir6. COVID-19'lu çocukların çoğunun yetişkinlere göre hastalığı daha az şiddetli geçirmesinin nedeni tam olarak belli olmamakla birlikte çocukların sıklıkla solunum yolu enfeksiyonları geçirdikleri ve virüse karşı yetişkinlerden daha yüksek antikor seviyelerine sahip olabileceği veya gelişmekte olan bağıșıklık sistemlerinin patojenlere yetişkinlerden daha farklı tepki verebileceği şeklinde tahmin edilmektedir ${ }^{6,7}$. Ayrıca hastalığın çocuklarda daha hafif seyretmesinin nedenleri olarak virüsün hücreye bağlanmasını sağlayan anjiotensin dönüştürücü enzim 2 (ACE-2) reseptör sayısının çocuklarda az olması ve çocukların bağışıklık sisteminin maturasyonunun tamamlanmaması nedeniyle sitokin firtınasının daha hafif olması gibi faktörler olduğu düşünülmektedir ${ }^{3}$. Bununla birlikte, bazı çocuklarda şiddetli alt solunum yolu enfeksiyonları, çoklu organ yetmezliği ve hatta ölüm görülebilmektedir.

Çocuklarda ve ergenlerde SARS-CoV-2 ile ilişkili ölüm nadirdir. Fransa, Almanya, İtalya, İspanya, Güney Kore, Birleşik Krallık ve Amerika Birleşik Devletleri'ni içeren bir çalışmada, çocuklar arasında (0 ila 19 yaş) COVID-19 ile ilişkili ölüm oranı Şubat 2021'e kadar 100.000 'de 0.17 olarak bildirilmiştir8.

Yetişkinlerde, hastaların yaklaşık \%5' i yoğun bakım gerektirirken, yoğun bakım gerektiren çocuk hastalara ilişkin bilgiler sınırlıdır' ${ }^{6}$. Çin'de ülke çapında yapılan 2.143 çocuğu içeren bir çalışmada, hastaların \%5,2 'sinde solunum sıkıntısı veya hipoksi olduğu ve $\% 0,6$ 'sında akut solunum sıkıntısı sendromu veya çoklu organ disfonksiyonu geliştiği bildirilmiştir6.

\section{Çocuklarda Ağır Hastalık İçin Risk Faktörleri}

Ağır hastalık tablosuna ilerleme riski olan çocukların erken dönemde tespit edilmesi hastaların yoğun bakım ünitelerine erken kabul 
edilip yakın klinik izlemine ve potansiyel olarak faydalı tedavileri vermeye olanak sağlayacaktır.

Pediatrik COVID-19'da kritik hastalık ve organ disfonksiyonu riskini belirlemede yararlı faktörler olarak; eşlik eden komorbit bir hastalık, 12 yaş üzeri olma, yüksek CRP değeri, yüksek WBC ve trombositopeni bildirilmiştir9. Çalışmalarda COVID-19' lu çocuklarda mekanik ventilasyon ihtiyacl, yüksek CRP ile ilişkilendirilmiştir ${ }^{10}$. Amerika'da yapılan bu çalışmada aynı zamanda infantlar ciddi hastalık açısından yüksek riskle ilişkilendirilmemekle birlikte obezite, hastalık şiddeti ile anlamlı olarak ilișkili bildirilmiștir ${ }^{10}$.

COVID-19' lu hastalarda saptanan düşük D vitamini ve fosfor düzeylerinin de kritik hastalıkla ilişkili olduğu gösterilmiştir ${ }^{11}$. Ülkemizde yapılan bir çalışmada da, çocuklarda düşük D vitamini düzeyi ile COVID-19 hastalığının gelişmesi arasında anlamlı bir iliş̧ki olduğu saptanmıştır ${ }^{12}$.

\section{Çocuk yoğun bakım ekibi için kişisel koruyucu önlemler}

Bir veya tekrarlanan nazal sürüntü numunesinin negatif sonuçlanması COVID-19' u dışlamada yeterli değildir. Bu nedenle, SARSCoV-2 PCR pozitif veya şüpheli çocukların bakımında her zaman tam kişisel koruyucu ekipman (KKE) giyilmelidir. Temas ve damlacık önlemleri ile birlikte N95 ve benzeri yüksek koruyuculuğu olan maskeler, gözlük veya siperlik kullanıldığında sağlık çalışanlarına bulaşmanın büyük ölçüde azaldığı gösterilmiştir ${ }^{13}$.

Bez maskeler de dahil olmak üzere yüz maskeleriyle temastan hemen önce ve sonra, el hijyeni yapılmalıdır. Aerosol üreten uygulamalaryüksek riskli oluğu için bu uygulamalar mümkün oldukça minumuma indirilmelidir (Tablo 1). Aerosol oluşturan prosedürlerden kaçınmak mümkün değilse, sağlık çalışanları için uygun KKE, N95 veya daha yüksek düzeyde koruma sunan diğer solunum aparatlarının kullanılması gerekir.

Tablo I : Aerosol üreten uygulamalar

- Yüksek akışlı nazal kanül oksijen
- Noninvaziv ventilasyon
- Balon maske ventilasyon
- Entübasyon
- Ventilatör devrelerinin ayrılması
- Trakeal aspirasyon (kapalı sistem olmadan)
- Ekstübasyon
- Öksürme / hapşırma veya buna neden olan herhangi bir
uygulama
- Göğüs fizyoterapisi
- Nebülize ilaç uygulaması (kapalı devre olmadıkça)
- Kardiyopulmoner resusitasyon (entübasyondan önce)

ÇOCUK YOĞUN BAKIM ÜNİTESİNDE COVID19 İLİŞKİLI SOLUNUM YETMEZLİĞì YÖNETIMI

\section{Non-invaziv Solunum Destek Tedavisi}

COVID-19 nedeniyle oksijen ihtiyacı olan hastalar için, başlangıç stratejisi olarak nazal kanül yoluyla düşük akış sistemiyle (4 L/dakikaya kadar) ek oksijenasyon desteği verilmesi uygundur. Düşük akış hızlarında viral aerosolizasyon derecesi tam olarak bilinmemekle birlikte muhtemelen minimum düzeyde olduğu düşünülmektedir. Çocuk hastalarda yeterli düzeyde oksijenizasyonu sağlamak için basit maske veya rezervuarlı oksijen maskesi kullanılabilmektedir. Hastada oksijen satürasyonu (Sp02) \% 92-96 olarak hedeflenmeli ve hasta ilk bir saat içerisinde tekrar değerlendirilmelidir. Hastaya verilen oksijen desteğinin yetersiz kalınması durumunda yüksek akışlı nazal kanül oksijen tedavisi (YANKOT) başlanılmalıdır. Bu tedavi sırasında nazal kanül üzerine maske takılması bulaş açısından fayda sağlayacaktır. YANKOT tedavisine rağmen Spo2 \%90' in altında seyreden çocuk hastalara noninvaziv mekanik ventilasyon (NIV) başlanılmalıdır. NIV tedavisi sırasında mümkün oldukça Helmet maske, 
bakteri-virüs filtresi veya ısı-nem filtresi (HME) kullanılmalıdır. Noninvaziv solunum desteği verilen hastaların negatif basınçlı odalarda tutulması ve bakım sağlayan sağlık çalışanlarının N-95 maskeleri dahil olmak üzere uygun KKE'leri kullanması gerekmektedir ${ }^{14}$. Tedavi ve izlem sirasinda Spo2'nin \%92'nin üzerinde tutulması hedeflenmelidir. Bazı durumlarda (uyku ve beslenme vb.) YANKOT ve NIV arasında kısa süreler için geçiş yapılabilir. YANKOT ve NIV ile takip edilen hastaların yakın olarak gözlenilmesi gerekmektedir. Sekresyonların kontrol edilemediği, aspirasyon riski olan, hemodinamik bozukluğu olan, multiorgan yetmezliği olan veya bozulmuş mental durumu olan çocuklarda NIV'den kaçınılmalıdır. Solunum iş gücünde artışla birlikte klinik durumda bozulma olması halinde entübasyon ve invaziv mekanik ventilasyon (IMV) başlanılmasında gecikme olmamalıdır. Gecikmiş entübasyon ve invaziv mekanik ventilasyon durumunda mortalite artmaktadır ${ }^{14}$.

\section{COVID-19'lu Hastalarda Entübasyon}

Erişkinlerde COVID-19 nedeniyle yoğun bakım ünitesine kabul edilen hastalarda entübasyon ve mekanik ventilasyon oranları yüksek düzeylerde bildirilmiștir ${ }^{15}$. Çocuk hastalarda bu oranlar düşük olmakla birlikte yoğun bakımda noninvaziv solunum desteğine klinik olarak yanıt alınamayan çocuk hastalara invaziv mekanik ventilasyon başlanılması kaçınılmazdır. Entübasyon işlemi mümkünse negatif basınçlı bir odada tüm enfeksiyon kontrol uyarıları dikkate alınarak yapılmalıdır. Entübasyondan önce bir kontrol listesi kullanılmalı ve ekip arasında nasıl iletişim kurulacağı planlanmalıdır. COVID-19'lu hastalar için özel oluşturulmuş trakeal entübasyon arabası kullanılması faydalı olacaktır.

Entübasyon işlemi sırasında oluşan aerosolların sağlık çalışanlarına bulaş riski yüksek olduğundan dolayı 3 kişi ile hızlı ardışık entübasyon protokolü uygulanması ve entübasyon işleminin en deneyimli hekim tarafından yapılması önerilmektedir 16. Entübasyon sırasinda aerosol oluşumunu azaltmak için mümkün olduğu kadar balon maske ile ventilasyondan kaçınılmalıdır 16. Hızlı ardışık entübasyon önerilmekle beraber öncesinde premadikasyon amaçlı sedasyonanaljezi ve zor havayolu hikayesi yok ise öksürüğü baskılamak için nöromuskuler bloker kullanılması önerilmektedir 16. Sedasyon, tercihen fentanil (1-2 $\mu \mathrm{g} / \mathrm{kg})$ veya ketamin (pulmoner hipertansiyon gibi kontrendikasyon yoksa 1-2 mg/kg) ile sağlanabilir. Roküronyum $(0,6-1,2 \mathrm{mg} / \mathrm{kg})$ kullanılarak nöromüsküler blokaj yapılabilir. Videolaringoskop olması durumunda entübasyon işleminin videolaringoskopla yapılması aerosol oluşmasını azaltarak sağlık çalışanlarının kontaminasyonunu azaltacaktır. Ayrıca işlem sırasında kaflı endotrakeal tüplerin kullanılması ve kapalı sistem endotrakeal aspirasyon uygun olacaktır.

\section{MEKANIK VENTILASYON TEDAVISI}

COVID-19 pnömonisinde genel olarak erken dönemde akciğer kompliyansı korunmakla birlikte düşük ventilasyon perfüzyondan dolayı hipoksemi gelişmektedir. Hipokseminin nedeni perfüzyon regülasyonunun kaybı ile açıklanabilirir. COVID-19 ile ilişkili solunum yetmezliği olan hastalar genellikle iki hafta veya daha uzun süreyle uzun süreli mekanik ventilasyona ihtiyaç duymaktadır.

COVID-19 ile ilişkili pediatrik akut respiratuvar distres sendromu (PARDS) nedeniyle mekanik olarak ventile edilen hastaların çoğu, kanıta dayalı ARDS stratejilerine göre yönetilmelidir.

Hastalığın erken evresinde akciğer kompliyansı normale yakın olduğundan yüksek PEEP (pozitif ekspiratuvar havayolu basincl) önerilmemektedir ${ }^{18}$. COVID-19 ilişkili PARDS'ye özgül bir tedavi olmamakla birlikte çocuk hastalarda altta yatan hastalığın tedavisi, 
akciğeri koruyucu ventilasyon stratejisi ve diğer destek tedavilerinin yapılması önerilmektedir. COVID-19 ilişkili PARDS tedavisinde prognozu etkileyen en önemli faktör mekanik ventilasyon stratejisidir. $\mathrm{Bu}$ nedenle $\mathrm{MV}$ ilişkili komplikasyonlardan ve sekonder hasardan kaçınmak oldukça önemlidir.

COVID-19 ilişkili PARDS hastaları için herhangi bir modun üstünlüğ̈ tam olarak gösterilememiştir. Volüm hedefli veya basınç hedefli ventilasyon modları kullanılabilir. En uygun olanı yoğun bakım ekibinin deneyimli olduğu modun kullanılmasıdır.

Ventilatör ilişkili akciğer hasarından kaçınmak için akciğer koruyucu ventilasyon stratejisi seçilmelidir. Hava yolu nemli ve sıcak tutulmalıdır. Uzun süreli sedasyondan kaçınılmalı ve hastalar mümkün olduğunca erken uyandırılıp pulmoner rehabilitasyon tedavilerine başlanmalıdır. Eğer hava yolu sekresyonları hava yolunu kapatıyorsa sekresyon aspirasyonu yapılmalıdır.

Hafif PARDS için hedef sp02 >\%92 kabul edilirken PEEP değeri en az $10 \mathrm{~cm}$ H2O olan PARDS'li hastalar ise daha düşük sp02 (\%8892) değerleri ile takip edilebilir. Siyanotik kalp hastalıkları, kronik akciğer hastalıklarında daha düşük oksijen saturasyon hedefleri belirlenir. Akciğer kompliyansının korunduğu PARDS durumlarında tidal hacim $5-8 \mathrm{ml} / \mathrm{kg}$, akciğer kompliyansının düștüğü durumlarda ise akciğerleri barotravmadan korumak için tidal hacim 3-6 ml/kg olarak ayarlanmalıdır. Her iki durumda da mekanik ventilasyonun kişiye özgü ayarlanması gerekir ve çocuğun yaşına uygun inspiryum süresi ile beraber FiO2 'nin \% 60 in altında tutulması tavsiye edilmektedir. Orta ve ağır PARDS li hastalarda mekanik ventilasyon ilişkili akciğer hasarını önlemek için permisif hiperkapniye izin verilebilir. Hedeflenen oksijen saturasyonu \%93-96, hedef $\mathrm{pH}$ değeri 7,25 üzerinde olması önerilmektedir ${ }^{19}$.
Ağır COVID-19 ilişkili PARDS hastalarında orta düzeyde PEEP seviyelerine (10-15 cm H2O) çıkılabilir. Plato basınçlarını yakın takip ederek PEEP değerlerini $15 \mathrm{~cm}$ H2O'nun üzerine çıkmak gerekebilir. PEEP artırılırken hemodinami, oksijen sunumu ve solunum sistemi kompliyansı yakından izlenilmelidir. Ağır oksijenasyon bozukluğu olan çocuklarda yavaş yavaş PEEP artırmayı ve azaltmayı içeren "akciğer açma manevraları" kullanılabilir.

Mekanik ventilasyon gerektiren pediatrik COVID-19 hastalarının sedasyonu önemlidir.

Çocuklarda sedasyon ve analjezi mekanik ventilasyon ile senkronizasyon ve toleransı sağlamak amacıyla kullanılır. Derin sedasyon yerine hafif sedasyon önerilir. Ek olarak, benzodiazepin dişı sedatifler ( propofol veya deksmedetomidin) benzodiazepin sakinleştiricilere göre tercih edilir. Yeterli sedasyon ve analjezinin sağlanması hastaların mekanik ventilasyona olan uyumunu artıracaktır ${ }^{20}$.

Sedasyonun yeterli olmadığı durumlarda kas gevşeticiler kullanılmakla birlikte kritik hastalık polinöropatisi ve miyopatisi risklerinden dolayı çocukların oldukça yakın izlenmesi gerekir. Panküronyum, roküronyum ve veküronyum gibi ilaçlar böbrek yetmezliğinde etkileri uzayabildiğinden ve yan etkileri artabileceğinden oldukça dikkatli kullanılmalıdır.

Daha çok erişkinlerde kullanılan prone pozisyonu çocuklarda da denenmişitir. Orta ve Ağır PARDS hastalarında hipoksemiyi azaltmada yardımcı olması beklenilmektedir ${ }^{19}$. Prone pozisyonundan fayda gören hastalar özellikle hastalığın ilk 3 gününde olmak üzere günde 12 saatten uzun süre yüzükoyun yatırılabilir. Sürfaktan tedavisi COVID-19 ilişkili PARDS'de rutin olarak önerilmemektedir.

Akciğer koruyucu ventilasyona rağmen refrakter hipoksemisi olan hastalarda 
ekstrakorporeal yaşam desteği (ECMO) için hastalar deneyimli merkezlere transfer edilmelidir. ECMO uygulaması, tedavi edilemeyen maligniteler, kitle etkisi oluşturan kafa içi kanamaya bağlı ciddi nörolojik bozukluklar, ölümcül kromozomal anormallikler gibi kontrendike durumlar dışında, tedaviye yeterli yanıt alınamayan ağır solunum yetmezliği, yüksek ventilatör basınçları, hiperkapnik solunum yetmezliği ve dirençli respiratuvar asidoz durumlarında erken dönemde (ilk 7 gün içinde) düşünülmelidir.

\section{Dolaşım Desteği}

COVID-19'lu çocuklar, taşikardiden, klasik şok ve kalp yetmezliği belirtilerine kadar oldukça farklı klinik prezantasyonlarla seyredebilir. Farklı çalışmalarda hasta çocuklarda taşikardi varlığı \%6 ile \%42 arasında değiş̧mektedir ${ }^{19}$.

Kardiyak hasar, troponin, kreatin kinaz (CK) ve izoenzimi (CK-MB), elektrokardiyogram (EKG) ve ekokardiyografik anormallikler gibi kardiyak belirteçlerle saptanabilir. Kardiyak hasar sonucu oluşabilecek myokardit ve aritmiler mortaliteyi 10 kata kadar artırabilir. Doğuştan veya edinsel kalp hastalığı gibi komorbiditeleri olan veya şiddetli hiperinflamatuvar faza ilerleyen çocuk hastalarda kalp hasarı oluşma riski artmıștır ${ }^{19}$.

Dolaşım yetmezliği olan pediatrik Covid-19 hastalarında ilk 1 saat içerisinde $10-20 \mathrm{ml} / \mathrm{kg}$ dan tercihen dengeli elektrolit çözeltilerle sıvı boluslarl, maksimum 40-60 ml/kg dan olacak şekilde yapılabilir ${ }^{19}$. Sıvı tedavilerinden sonra kapiller dolum zamanı (KDZ), nabız, kan basıncı, solunum sesleri, karaciğer büyüklüguü ve idrar çıkışı değerlendirilmelidir ${ }^{21}$.

COVID-19 ve dolaşım yetmezliği olan çocuklarda yaşa uygun ortalama arter basıncı hedeflenmekle beraber yeterli donanımı olmayan merkezlerde sistolik kan basincı takipleri yapılabilir ${ }^{19}$. Kan laktat düzeylerinin artışı dolaşımı bozuk olan hastalarda mortaliteyle ilişkilidir ${ }^{21}$.

Sivı tedavisine cevap vermeyen COVID-19 tanılı çocuklarda dopamin yerine epinefrin veya norepinefrin uygulanmalıdır. Seyreltilmiş solüsyon, santral venöz erişim yoksa periferik bir intravenöz kateter aracılı̆̆ılyla başlatılabilir. Zayıf perfüzyonlu şok durumunda; Epinefrin (0.02-0.05 $\mathrm{mcg} / \mathrm{kg} / \mathrm{dk}$ ) başlanır taşikardi açısından dikkatli olunmalıdır, zayıf perfüzyon düzelmiyor ise Milrinon $(0,25 \quad-\quad 0,5$ $\mathrm{mcg} / \mathrm{kg} /$ dak) eklenir ${ }^{18}$.

Normal/Hiperperfüzyonlu şok durumunda ise; Norepinefrin $(0.02-0.05 \mathrm{mcg} / \mathrm{kg} / \mathrm{dk})$ başlanır miyokardiyal disfonksiyona dikkat edilmelidir; katekolamine dirençli hipotansiyon varsa Vazopressin başlanır ${ }^{18}$.

Sivi tedavisine ve inotropik tedaviye cevap vermeyen şok durumunda glukokortikoidler antiinflamatuvar dozda verilebilir. Kardiyak fonksiyonlar düzelmez ise Levosimendan başlanması açısından hasta değerlendirilmelidir.

Güney Kore ve Japonya'da yapılan araştırmalar sonucunda, maksimum tıbbi tedaviye yanit vermeyen COVID-19'un neden olduğu ARDS ve/veya kalp yetmezliğinin (miyokardit, aritmiler, pulmoner emboli) tedavisinde ECMO'nun kullanılması önerilmektedir ${ }^{19}$.

\section{Destek tedaviler}

Tüm kritik çocuk hastaların takip ve tedavisinde beslenme önemlidir. Yoğun bakımdaki çocuk hastalarda malnütrisyon ile mortalite, morbidite ve artmış yoğun bakımda kalış süresi arasında ilişki saptanmıştır. Mekanik ventilatöre bağlı çocuk hastalarda kontrendike bir durum olmadığı sürece erken dönemde enteral beslenmeye başlanılması önerilmektedir ${ }^{18}$.

Kardiyak kökenli olmayan akciğer ödemi durumunda sıvı dengesinin sağlanması 
önemlidir. Yoğun bakımlarda takip edilen çocuk hastalarda iyi bir hemodinaminin ve kritik organ perfüzyonunun sağlanması için intravasküker hacmin yeterli olması gerekir. Uygunsuz bir şekilde fazla sıvı verilmesi akciğer ödemine yol açarak gaz alışverişini olumsuz etkileyebilir. Hemodinamik olarak stabil olan ve septik şokta olmayan kritik çocuk hastalarda sıvı dengesini negatifte tutmak akciğer fonksiyonları üzerine olumlu etki sağlar. Diüretik tedavisine yanıtsız böbrek yetmezliğinde ve/veya \%10'dan fazla sıvı yükü olanlarda renal replasman tedavisi düşünülmelidir.

\section{Transfüzyon}

Yoğun bakımlarda takip edilen çocuk hastalarda hemoglobin $7 \mathrm{gr} / \mathrm{dl}$ üzerinde tutulmalıdır. Ancak çocuk hastalarda ağır hipoksi varsa ve/veya kan gazında laktat düzeyi $4 \mathrm{mmol} / \mathrm{L}$ üzerinde ise hemoglobin düzeyinin $10 \mathrm{gr} / \mathrm{dl}$ üstünde olması hedeflenir ${ }^{18}$.

\section{Tedavi}

Pediatrik COVID-19 hastaları için günümüzde standart bir tedavi yöntemi olmamakla beraber yetişkin hastaların verilerinden kazanılan stratejilerle pediyatrik hastalar yönetilmektedir.

Yetişkinlerde farmakolojik olarak virüs yükünü azaltmak için antiviral tedaviler, hiperinflamasyonu önlemek için kortikosteroid ve biyolojik ajanlar, protrombotik olarak antitrombotik tedaviler uygulanmaktadır.

Kültür ve antibiyogram sonuçlarına göre sadece sekonder bakteriyel enfeksiyonu olan hastalarda antibiyotik kullanılmalıdır. Günümüzde pediatrik COVID-19 tedavisinde, azitromisin, hidroksiklorokin, lopinavir ve ritonavir önerilmemektedir ${ }^{22}$. Kanıtlanmamış faydalarına rağmen, belgelenmiş şiddetli veya kritik COVID-19'lu çocuklar için antiviral tedavi önerilmektedir ${ }^{22}$. 12 yaş üzeri çocuklarda Favipiravir 5 gün süre ile kullanılabilir.
Favipiravirv virüs üzerinde RNA polimerazı inhibe ederek etkisini gösterir. Bu şekilde virüs

gen çoğalmasını durdurarak virüsle enfekte hücrede virüsün çoğalmasını önler. Bir başka anti viral ilaç olan Remdesivir, RNA'ya bağımlı RNA polimerazı inhibe eden ve koronavirüslere karşı aktiviteye sahip olan bir nükleotid analoğunun ön ilacıdır 23. Remdesevir, 3,5 kg ile $40 \mathrm{~kg}$ arasında olan hastalarda 1 . günde 5 $\mathrm{mg} / \mathrm{kg}$ intravenöz (IV) yükleme dozu, ardından her 24 saatte bir $2.5 \mathrm{mg} / \mathrm{kg} \mathrm{IV}, 40 \mathrm{~kg}$ üzerinde olan hastalar içinde 1. günde $200 \mathrm{mg}$ IV yükleme dozu, ardından her 24 saatte bir $100 \mathrm{mg}$ IV olarak uygulanmaktadır. Önerilen tedavi süresi 5 gün olmakla beraber kritik hastalığa sahip çocuklar için tedavi süresi 10 güne tamamlanabilir ${ }^{24,25}$.

Glukokortikoidler erişkin hastalarda azalmış mortalite ile ilişkilendirilmiş olsa da, çocuklarda çalışmalar devam etmektedir. Mekanik ventilasyon ihtiyacı olan ağır solunum sıkıntısı yaşayan çocuk hastalarda kortikosterod tedavisi uygulanabilir. Rehberlerde Deksametazon $0,2-0.4 \mathrm{mg} / \mathrm{kg}$ gün günde bir kez (maksimum doz $6 \mathrm{mg}$ ), Prednizolon $1 \mathrm{mg} / \mathrm{kg}$ oral veya NG günde bir kez (maksimum doz 40 $\mathrm{mg}$ ), Metilprednizolon 1-2 mg/kg IV günde bir kez (maksimum doz $80 \quad \mathrm{mg}$ ) olarak önerilmektedir.

Ayrıca yetişkin hastalarda kullanılan biyolojik ajanlardan tosilizumab (IL-6 antagonisti) ve anakinra (IL-1 antagonisti) tedavisinin pediatrik hastalarda kullanılmasıyla alakalı yeterli veri yoktur ${ }^{26}$.

\section{MIS-C (ÇOKLU SISTEMIK INFLAMATUVAR SENDROM)}

İlk olarak Nisan 2020'de Birleşik Krallık'tan COVID-19 hastalığı ile ilişkili olduğu düşünülen inkomplet Kawasaki hastalığına veya toksik şok sendromuna benzeyen ve birçok

sistemi tutan hiperinflamasyonla seyreden olgular bildirilmiştir ${ }^{27}$. Sonrasında ABD ve İtalya başta olmak üzere dünyanın çeşitli 
ülkelerinden de benzer olgular bildirilmeye başlanmıştır. Mayıs 2020' de ABD Hastalık Kontrol ve Önleme Merkezi (CDC) tarafindan ilk kez yeni bir COVID-19 başvuru şekli bildirilmiştir. $\mathrm{Bu}$ klinik tablo çocuklarda, COVID-19 ile olası ilişkili çoklu sistemik inflamatuvar sendrom (MIS-C) olarak tanımlanmıştır. Bu hasta çocukların çoğu, komplet veya inkomplet Kawasaki hastalığı kriterlerini karşılamaktaydı.

Dermatolojik, mukokutanöz ve gastrointestinal belirtilere sahip bu hiperinflamatuvar sendromda, kardiyak disfonksiyon ve kalp yetersizliği daha çok ön planda görülmektedir ${ }^{28,29}$. MIS-C sendromu düşünülen hastaların oldukça hızlı bir şekilde tedavi edilmesi gerekmektedir.

Hastalık Kontrol ve Önleme Merkezi'ne göre 21 yaşından küçük kişilerde bu hastalık tablosunu yapacak başka alternatif tanıların olmaması şartıyla aşağıdaki 4 kriterin hepsini sağlaması gerekmektedir (Tablo 2) 27-29.

Tablo II: CDC- Çocuklarda MIS-C tanımlama kriterleri

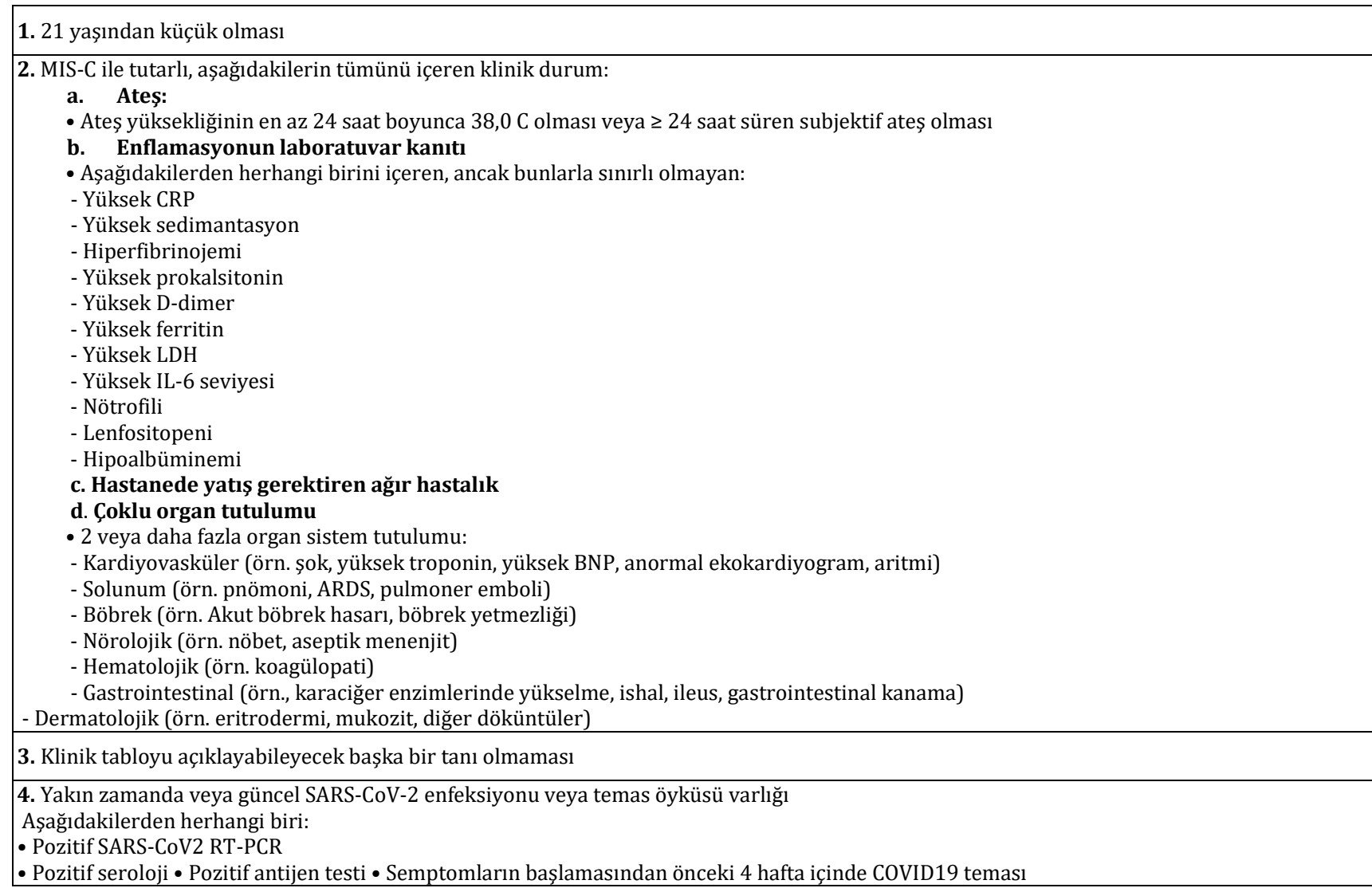

783 MIS-C tanılı hastayı içeren bir çalışmada hastalarda yüksek ateșin en sik semptom olduğu daha sonrasında gastrointestinal sistem ile alakalı (\%71) semptomların çok sık görüldüğü bildirilmiştir ${ }^{30}$.

MIS-C klinik olarak Kawasaki Hastalığı (KH) ve Toksik şok sendromu (TŞS) ile benzerlik göstermektedir, bu nedenle ayırıcı tanısının oldukça dikkatli yapılması gerekmektedir. MIS$C$ genellikle daha büyük çocukları ve ergenleri etkilerken, klasik $\mathrm{KH}$ tipik olarak bebekleri ve küçük çocukları (\%80'i 5 yaşın altı çocuklar) etkiler. MIS-C'de gastrointestinal semptomlar (özellikle karın ağrısı) çok yaygın iken, bu semptomlar klasik KH'de daha az belirgindir. Klasik KH ile karşılaş̧tırıldığında MIS-C'de 
miyokardiyal disfonksiyon ve şok daha sık görülür ${ }^{31}$. İnflamatuvar belirteçler (özellikle CRP, ferritin ve D-dimer), klasik $\mathrm{KH}$ ile karşılaştırıldığında MIS-C'de daha yüksek olma eğilimindedir ${ }^{32}$. TŞS ve MIS-C'de trombositopeni beklenirken, KH'de trombositoz görülür. MIS-C'de daha çok myokardit ve perikardit gözlemlenirken KH'de ise myokardit nadir görülür. TŞS'de kardiyovasküler sistem komplikasyonları pek beklenmez ${ }^{33}$.

MIS-C tedavisi multidisipliner yaklaşım gerektiren içerisinde çocuk enfeksiyon, çocuk kardiyoloji, çocuk romatoloji, çocuk yoğun bakım uzmanlarının bulunduğu bir ekip tarafından yönetilmelidir. Hastalığın klinik seyrine göre tedavi planlanmalıdır (Tablo 3). Orta ve şiddetli belirti gösteren hastalara ampirik antimikrobiyal tedavi, kortikosteroid tedavisi, profilaktik antitrombotik tedavi ve intravenöz immün globulin (IVIG) tedavisi başlanılması uygundur ${ }^{33}$. İntravenöz puls metilprednizolonun (3-7 gün süreyle 10-30 mg / kg / gün, sonrasında oral prednizolonun kademeli olarak azaltılarak) yararlı olduğu bulunmuștur. $\mathrm{KH}$ benzeri hastalık seyri gösteren hastalara aspirin 20-25 $\mathrm{mg} / \mathrm{kg} / \mathrm{doz}$ (80-100 mg / kg / gün) ve IVIG 2 g/kg'dan verilmesini önerilmiştir. Diğer tedavi yöntemleri arasında ikinci IVIG dozu, infliksimab, tosilizumab ve anakinra yer almaktadır ${ }^{34,35 .}$

Tablo III: MIS-C Tedavisi

\section{Tüm Hastalar}

- Tüm hastalara antibiyotik başlanır; klinik durum ve kültür sonuçlarına göre devamına karar verilir.

- Septik ŞOK ve/veya menenjit düşünülüyorsa seftriakson +/- vankomisin, İmmun yetmezlikli hastalarda sefepim +/- vankomisin,

- Abdominal patoloji/perforasyon varsa tedaviye metronidazol eklenir

- Toksik ŞOK şüphesinde(Özellikle hipotansif hastalarda) klindamisin eklenir.

\section{Hafif MIS-C}

- IVIG $2 \mathrm{~g} / \mathrm{kg}$ IV (maksimum $100 \mathrm{~g}$ )/12 saat infüzyon

- Metilprednisolon $2 \mathrm{mg} / \mathrm{kg} /$ gün (maksimum $60 \mathrm{mg} / \mathrm{gün}$ ) iki doz, (1 hafta tedaviden sonra 2-3 haftada azaltılarak kesilir)

- Asetilsalisilik asit (ASA) $3-5 \mathrm{mg} / \mathrm{kg} /$ gün (tek doz) (maksimum $100 \mathrm{mg} /$ gün)(Bazı yayınlarda maksimum $325 \mathrm{mg}$ ) veya Enoksaparin (proflaksi dozu) $1 \mathrm{mg} / \mathrm{kg} / \mathrm{doz}$ (100 IU/kg/doz) (günde $1 \mathrm{kez}$ ) SC

- Mide koruyucu

- Tuzsuz Diyet

Orta MIS-C

- IVIG 2 g/kg IV (maksimum $100 \mathrm{~g}$ )/12 saat infüzyon

- Metilprednisolon Pulse: $10 \mathrm{mg} / \mathrm{kg} /$ gün (100 cc SF içinde 1 saat infüzyon) (1 gün)( tek doz Maksimum $1 \mathrm{gr}$ ) sonrasında $2 \mathrm{mg} / \mathrm{kg} / \mathrm{gün}$ ikiye bölünmüş dozda (maksimum $60 \mathrm{mg} /$ gün) (1 hafta tedaviden sonra 2-3 haftada azaltılarak kesilir)

- Enoksaparin (tedavi dozu) $1 \mathrm{mg} / \mathrm{kg} / \mathrm{doz}$ (100 IU $/ \mathrm{kg} / \mathrm{doz}$ ) (günde $2 \mathrm{kez}$ ) SC

- Mide koruyucu

- Tuzsuz Diyet

VAKİT KAYBETMEDEN

Hafif veya orta şiddetli PIMS'de tedavi başlangıcından 24 saat sonra tedavi cevabı yoksa/yetersizse

Șiddetli ŞOK, Șiddetli LV(sol ventrikül) Disfonksiyonu, MODS veya klinik kötüleșme durumunda metilprednizolon Pulse: $30 \mathrm{mg} / \mathrm{kg} / \mathrm{gün}$ (100 cc SF içinde 1 saat infüzyon) (maks. 1gr) (3 gün), sonrasında $2 \mathrm{mg} / \mathrm{kg} /$ gün IV (maksimum $60 \mathrm{mg} /$ gün) ikiye bölünmüş dozda. (1 hafta tedaviden sonra 2-3 haftada azaltılarak kesilir. Gerekirse steroid tedavisi 2 hafta verilebilir)

- Mide koruyucu・Tuzsuz Diyet

(Anakinra 2-10 mg/kg/gün IV [süre: 5 - 14 gün])(Maksimum 100mg/doz)

Ağır MIS-C

IVIG $2 \mathrm{~g} / \mathrm{kg}$ IV (maksimum $100 \mathrm{gr}$ ) $/ 12$ saat infüzyon

Metilprednisolon Pulse: 30 mg/kg/gün (100 cc SF içinde 1 saat infüzyon) (max 1gr) (3 gün) sonrasında $2 \mathrm{mg} / \mathrm{kg} /$ gün IV (maksimum $60 \mathrm{mg} /$ gün) ikiye bölünmüş dozda. (1 hafta tedaviden sonra 2-3 haftada azaltılarak kesilir. Gerekirse steroid tedavisi 2 hafta verilebilir)

Anakinra (IL-1 Reseptör Antagonisti) $10 \mathrm{mg} / \mathrm{kg} /$ gün IV(süre: 5 - 14 gün)

Enoksaparin (tedavi dozu) $1 \mathrm{mg} / \mathrm{kg} / \mathrm{doz}(100 \mathrm{IU} / \mathrm{kg} / \mathrm{doz}$ ) (günde $2 \mathrm{kez}$ ) SC

Tedavi cevabı yoksa/yetersizse

Plazmaferez (Hasta genel durumu çok kötü bir tabloda başvurmuşsa plazmaferez + hemen sonrasında diğer tedaviler (IVIG + pulse steroid +anakinra) birlikte verilebilir. 


\section{MIS-C antiplatelet ve antikoagülan terapi ${ }^{34,35}$}

- D-Dimer $\geq 3000 \mathrm{ng} / \mathrm{mL}$ ise tedavi dozunda enoksoparin; $1 \mathrm{mg} / \mathrm{kg} / \mathrm{doz}$ (100 IU/kg/doz) (günde 2 kez-SC).

- D-Dimer 1000 ile $3000 \mathrm{ng} / \mathrm{mL}$ arasında ise proflaksi dozunda enoksoparin: $1 \mathrm{mg} / \mathrm{kg} / \mathrm{doz}$ (100 IU/kg/doz) (günde tek kez-SC).

- D-Dimer 200-1000 ng/mL arasinda ise proflaksi dozunda enoksoparin veya $5 \mathrm{mg} / \mathrm{kg} /$ gün tek doz aspirin.

- D-Dimer < $200 \mathrm{ng} / \mathrm{mL}$ ise $5 \mathrm{mg} / \mathrm{kg} /$ gün tek doz aspirin.

- MIS-C tanısı alan tüm hastalar en az 6 hafta düşük doz aspirin almalıdır.

- ASA tedavisi, kanama riski yüksek hastalara ve trombosit değerleri $80.000 / \mathrm{mm} 3$ altında olanlara verilmez.

- Enoksaparin tedavisi, hastada herhangi bir tromboz gelişmemişse ve organ disfonksiyonu mevcut değilse taburculuktan sonraki21. gün kontrolünde kesilmelidir (Kontrollerde antifaktör Xa düzeyi: 0.5-1 arasında olması sağlanmalıdır).

- Oral prednol tedavisi kesildikten sonra mide koruyucu tedavisi de kesilecektir. Steroidlerin, dozdan bağımsız olarak 2-3 haftalık azaltma süreci olmalıdır.

\section{MIS-C Taburculuk Kriterleri ${ }^{34,35}$}

- Genel durumu iyi, vital bulguları stabil, en az 72 saattir ateşsiz

- Akut faz reaktanları (CRP, prokalsitonin, BNP, D- dimer) belirgin düşme eğiliminde (son 96 saat içerisinde en az 24 saat ara ile alınan 3 örnekte düşme eğilimi görülmeli)

- Oral alımı iyi, enteral besleniyor, bulantı kusma yok, ağızdan ilaç (steroid ve/veya aspirin) alabiliyor olmalı

- Trombosit değerlerinde düşme eğilimi yok ve normal sınırlar içerisinde
- Son 48 saat içerisindeki EKG normal

- Son EKO bulguları normal veya stabil

- Oksijen desteği almıyor (en az 48 saattir)

- Takip planı yapılabilen, uyumlu aile

Çıkar Çatışması Beyanı: Yazarlar çıkar çatışması olmadığını bildirmişlerdir.

Finansal Destek: Bu çalışma her hangi bir fon tarafından desteklenmemiştir.

Declaration of ConflictingInterests: The authors declare that they have no conflict of

interest.

Financial Disclosure: No financial support was received.

\section{KAYNAKLAR}

1. Weiss SR, Navas-Martin S. Coronavirus pathogenesis and the emerging pathogen severe acute respiratory syndrome coronavirus. Microbiol Mol Biol Rev. 2005; 69: 635-64.

2.Singhal T. A Review of Coronavirus Disease-2019 (COVID-19). Indian J Pediatr. 2020; 87: 281-6.

3. Sankar J, Dhochak N, Kabra SK, et al. COVID-19 in Children: Clinical Approach and Management. Indian J Pediatr. 2020; 87: 433-42.

4. Van Doremalen N, Bushmaker T, Morris DH, et al. Aerosol and Surface Stability of SARS-CoV-2 as Compared with SARS-CoV-1. N Engl J Med. 17 Mart 2020;NEJMc2004973.

5. Chan JF-W, Yuan S, Kok K-H, et al. A familial cluster of pneumonia associated with the 2019 novel coronavirus indicating person-to-person transmission: a study of a family cluster. Lancet. 2020; 395(10223): 514-23.

6. Yılmaz K, Gozupirinççioğlu A, Aktar F, et al. Evaluation of the novel coronavirus disease in Turkish children: Preliminary outcomes. Pediatr Pulmonol. 2020; 55: 3587-94.

7. Dong Y, Mo X, Hu Y, et al. Epidemiology of COVID19 Among Children in China. Pediatrics. Haziran 2020; 145: 20200702. 
8. Bhopal SS, Bagaria J, Olabi B, et al. Children and young people remain at low risk of COVID-19 mortality. Lancet Child Adolesc Health. 2021; 5: e123.

9. Fisler G, Izard SM, Shah S, et al. Characteristics and risk factors associated with critical illness in pediatric COVID-19. Annals of Intensive Care, (2020); 10: 171.

10. Zachariah $\mathrm{P}$, Johnson $\mathrm{CL}$, Halabi $\mathrm{KC}$, et al. Epidemiology, Clinical Features, and Disease Severity in Patients With Coronavirus Disease 2019 (COVID-19) in a Children's Hospital in New York City, New York. JAMA Pediatrics. 2020; 174: 202430.

11. lie PC, Stefanescu S, Smith L. The role of vitamin D in the prevention of coronavirus disease 2019 infection and mortality. Aging Clinical and Experimental Research. 2020: 1. Clin Experiment Res. 2020; 1.

12. Yılmaz K, Şen V. Is vitamin D deficiency a risk factor for COVID-19 in children? Pediatr Pulmonol. Aralık 2020; 55: 3595-601.

13. Cheng VCC, Wong S-C, Chen JHK, et al. Escalating infection control response to the rapidly evolving epidemiology of the coronavirus disease 2019 (COVID-19) due to SARS-CoV-2 in Hong Kong. Infect Control Hosp Epidemiol. 2020; 41: 493-8.

14. Raoof S, Nava S, Carpati C, et al. High-Flow, Noninvasive Ventilation and Awake (Nonintubation) Proning in Patients With Coronavirus Disease 2019 With Respiratory Failure. Chest. 2020; 158: 1992-2002.

15. Grasselli G, Zangrillo A, Zanella A, et al. Baseline Characteristics and Outcomes of 1591 Patients Infected With SARS-CoV-2 Admitted to ICUs of the Lombardy Region, Italy. JAMA. 2020; 323: 1574-81.

16. Matava CT, Kovatsis PG, Summers JL, et al. Pediatric Airway Management in Coronavirus Disease 2019 Patients: Consensus Guidelines From the Society for Pediatric Anesthesia's Pediatric Difficult Intubation Collaborative and the Canadian Pediatric Anesthesia Society. Anesth Analg.2020; 10.1213.

17. Gattinoni L, Chiumello D, Caironi P, et al. COVID19 pneumonia: different respiratory treatments for different phenotypes? Intensive Care Med.2020; 46: 1099-102.

18. COVID 19 PARDS Yönetimi, Çocuk Acil Tıp ve Yoğun Bakım Derneği, Protokoller, 2020

19. Kache S, Chisti MJ, Gumbo F, et al. COVID-19 PICU guidelines: for high- and limited-resource settings. Pediatr Res. 2020; 88: 705-16.

20. Ammar MA, Sacha GL, Welch SC, et al. Sedation, Analgesia, and Paralysis in COVID-19 Patients in the Setting of Drug Shortages. J Intensive Care Med. 2021; 36: 157-74.

21. Alhazzani W, Møller MH, Arabi YM, et al. Surviving Sepsis Campaign: Guidelines on the Management of Critically Ill Adults with Coronavirus Disease 2019 (COVID-19). Crit Care Med. 2020; 10.1097

22. Hernandez AV, Roman YM, Pasupuleti V, et al. Hydroxychloroquine or Chloroquine for Treatment or Prophylaxis of COVID-19: A Living Systematic Review. Ann Intern Med. 2020; 173: 287-96.

23. COVID-19: Management in children - UpToDate . Erişim adresi: https: // www. uptodate.com/ contents/ covid-19-management-in-children

24. Wang M, Cao R, Zhang L, et al. Remdesivir and chloroquine effectively inhibit the recently emerged novel coronavirus (2019-nCoV) in vitro. Cell Res. 2020; 30: 269-71.

25. Chiotos K, Hayes M, Kimberlin DW, et al. Multicenter Interim Guidance on Use of Antivirals for Children With Coronavirus Disease 2019/Severe Acute Respiratory Syndrome Coronavirus 2. J Pediatric Infect Dis Soc. 2021; 10: 34-48.

26. Rochwerg B, Agarwal A, Siemieniuk RA, et al. A living WHO guideline on drugs for covid-19. BMJ. 2020; 370: m3379.

27. Riphagen S, Gomez X, Gonzalez-Martinez C, et al. Hyperinflammatory shock in children during COVID-19 pandemic. Lancet. 2020; 395(10237): 1607-8.

28. Dufort EM, Koumans EH, Chow EJ, et al. Multisystem Inflammatory Syndrome in Children in New York State. N Engl J Med. 2020; 383: 347-58. 
29. Türe M, Kan A, Akın A, et al. Multisystem inflammatory syndrome in children: A single-center experience. Pediatrics International. 2021.

30. Radia T, Williams N, Agrawal P, et al. Multisystem inflammatory syndrome in children \& adolescents (MIS-C): A systematic review of clinical features and presentation. Paediatr Respir Rev. 2021; 38: 51-7.

31. Feldstein LR, Rose EB, Horwitz SM, et al. Multisystem Inflammatory Syndrome in U.S. Children and Adolescents. N Engl J Med. 2020; 383: 334-46.

32. Whittaker E, Bamford A, Kenny J, et al. Clinical Characteristics of 58 Children With a Pediatric Inflammatory Multisystem Syndrome Temporally Associated With SARS-CoV-2. JAMA. 2020; 324: 25969.
33. COVID-19: Multisystem inflammatory syndrome in children (MIS-C) clinical features, evaluation, and diagnosis - UpToDate [2021]. Erişim adresi: https://www.uptodate.com/contents/covid-19multisystem-inflammatory-syndrome-in-childrenmis-c-clinical-features-evaluation-and-diagnosis

34. Türe M, Akın A Kan A, et al. MIS-C ( Multisystem İnflamatory Syndrome İn Children)- Pıms-Ts (Pediatric İnflamatory Multisystem Syndrome Temporally Associated With Covid-19) Rehberi, Dicle Üniversitesi Tıp Fakültesi Çocuk Sağlığı Ve Hastalıkları AD, 2021.

35. Rowley AH. Understanding SARS-CoV-2-related multisystem inflammatory syndrome in children. Nat Rev Immunol. 2020; 1-2. 